\title{
Combating Plagiarism in Nursing Research
}

\author{
Kusum Sharma ${ }^{1}$, Kuldeep K Ashta ${ }^{2}$
}

\begin{abstract}
Plagiarism is wrongful appropriation and an unethical activity and is one of the most common forms of scientific misconduct and academic dishonesty that leads to rejection of many nursing research articles and retraction of the published articles. The reported cases of plagiarism are just the tip of the iceberg, and it is the responsibility of nursing educators, authors, and editors to formulate a zero tolerance against plagiarism. We need to reduce the engagement of students in dishonest behaviors and the potential transfer of this dishonest behavior to the clinical setting. This article discusses various types of plagiarism, its causes, detection of plagiarism, and the responsibility of nursing educators, authors, and editors in preventing/reporting plagiarism in articles they come across. It also emphasizes on regular use of plagiarism detection tools and formulation of anti-plagiarism committees which will ensure publication ethics.

Keywords: Faculty, Nursing, Nursing research, Plagiarism, Scientific misconduct. Journal of Medical Academics (2020): 10.5005/jp-journals-10070-0047
\end{abstract}

\section{INTRODUCTION}

The basic professional role of a nurse requires certain qualities such as integrity and trustworthiness. When it comes to honesty and ethics, nursing has been ranked highest among all professions, ${ }^{1}$ but despite this, the profession has been struggling with the impact of plagiarism.

The inability of educators and journal editors to recognize address plagiarism adds to the complexity of this issue. Therefore, providing training on what constitutes plagiarism must be encouraged among nursing educators. In addition, student researchers must be sensitized about the definition of plagiarism, the importance of giving the credit to the reference source in an appropriate manner, and checking for plagiarism in the manuscript before submitting for review and publication. Studies have shown the positive impact of such educational interventions on addressing the issue of plagiarism in nursing research. ${ }^{2}$

\section{Causes/Reasons}

- Unreal expectations-Nursing faculty often have unreal expectations from student researchers, giving rise to plagiarism.

- Personal perception-Both students and educators assumed that plagiarism is deeply rooted in field of research and make their own perception to first there plagiarism act in the form of unintentional plagiarism.

- Lack of standardization-Non-standard styles of writing and citing may lead to unintentional plagiarism, whereas following the standard methods advised by regulatory bodies will assist in avoiding unintentional plagiarism.

- Goals-To comply with requirement of recognition, mandatory publication pressure from regulatory bodies on a researcher will lead to plagiarism.

- Easy access to internet-Availability of literature on the Internet eases the process of plagiarism.

\section{Types of Plagiarism}

The following table lists 10 types of plagiarism with brief definitions and ratings of commonness and seriousness Table $1 .^{3}$ \begin{tabular}{l}
\hline \hline${ }^{1}$ Department of Medicine, Base Hospital, Srinagar, India \\
${ }^{2}$ Department of Medicine, Army College of Medical Sciences, Delhi \\
Cantonment, New Delhi, India \\
Corresponding Author: Kuldeep K Ashta, Department of Medicine, \\
Army College of Medical Sciences, Delhi Cantonment, New Delhi, \\
India, Phone: +91 9545046456, e-mail: kuldeepashta@gmail.com \\
How to cite this article: Sharma K, Ashta KK. Combating Plagiarism in \\
Nursing Research. J Med Acad 2020;3(1):25-26. \\
Source of support: Nil \\
Conflict of interest: None \\
\hline \hline
\end{tabular}

\section{How to Control/Stop Plagiarism}

\section{General Points}

- Creating awareness why students cheat

- Educate yourself (student/author/editor/educator) about plagiarism

- Discuss the benefits of citing sources and giving credit to the references

- Make the penalties clear

- Use of plagiarism detection tools (PDTs)

\section{Responsibility of Educators}

"A teacher affects eternity; he can never tell where his influence stops." Henery Brooks Adams

- Teaching students about criteria/guidelines and publication ethics, which will inculcate moral values in students

- Avoid keeping unrealistic values from student researchers

- Teach students standard techniques of writing and citing sources

- Creating awareness in students about consequences of plagiarising i.e., it may lead to rejection of submitted manuscript and retraction of the published one

\section{Responsibility of Authors}

"...We write to taste life twice, in the moment and in retrospection" Anais Nin

() The Author(s). 2020 Open Access This article is distributed under the terms of the Creative Commons Attribution 4.0 International License (https://creativecommons. org/licenses/by-nc/4.0/), which permits unrestricted use, distribution, and non-commercial reproduction in any medium, provided you give appropriate credit to the original author(s) and the source, provide a link to the Creative Commons license, and indicate if changes were made. The Creative Commons Public Domain Dedication waiver (http://creativecommons.org/publicdomain/zero/1.0/) applies to the data made available in this article, unless otherwise stated. 
Table 1: Types of plagiarism with brief definitions and ratings of commonness and seriousness

\begin{tabular}{|c|c|c|c|}
\hline Type & Also known as & Definition & $\begin{array}{l}\text { Commonness/ } \\
\text { seriousness out of } 10\end{array}$ \\
\hline $\begin{array}{l}\text { Secondary } \\
\text { source }\end{array}$ & Inaccurate citation & $\begin{array}{l}\text { Citing primary sources contained in a secondary source, } \\
\text { such as meta-analysis }\end{array}$ & $6.9 / 6.4$ \\
\hline Invalid source & $\begin{array}{l}\text { Fabrication/ } \\
\text { falsification }\end{array}$ & Referencing incorrect/nonexistent sources & $3.9 / 7.3$ \\
\hline Duplication & Self plagiarism reuse & Reusing work from their own previous studies/papers & $6.3 / 6.5$ \\
\hline Paraphrasing & $\begin{array}{l}\text { Plagiarism } \\
\text { intellectual theft }\end{array}$ & $\begin{array}{l}\text { Taking another person's writing and changing the words } \\
\text { and not citing the source }\end{array}$ & 7.5/7.6 \\
\hline $\begin{array}{l}\text { Repetitive } \\
\text { research }\end{array}$ & Self plagiarism reuse & $\begin{array}{l}\text { Repeating data/text from a similar study without proper } \\
\text { attribution }\end{array}$ & 7.1/7.6 \\
\hline Replication & $\begin{array}{l}\text { Author submission } \\
\text { violation }\end{array}$ & $\begin{array}{l}\text { Submitting apaper to multiple publications, resulting in } \\
\text { same manuscript published more than once }\end{array}$ & $4.2 / 7.7$ \\
\hline $\begin{array}{l}\text { Misleading } \\
\text { attribution }\end{array}$ & $\begin{array}{l}\text { Inaccurate } \\
\text { authorship }\end{array}$ & $\begin{array}{l}\text { Inaccurate/insufficient list of authors either denying } \\
\text { contribution or listing one who made no contributions }\end{array}$ & $4.8 / 8.2$ \\
\hline $\begin{array}{l}\text { Unethical } \\
\text { collaboration }\end{array}$ & $\begin{array}{l}\text { Inaccurate } \\
\text { authorship }\end{array}$ & $\begin{array}{l}\text { Using written work/outcomes or ideas which do not } \\
\text { acknowledge the collaboration }\end{array}$ & $5.3 / 8.2$ \\
\hline $\begin{array}{l}\text { Verbatim } \\
\text { plagiarism }\end{array}$ & Copy and paste & $\begin{array}{l}\text { Copying of another's words and works without providing } \\
\text { proper attribution }\end{array}$ & $2.3 / 8.4$ \\
\hline $\begin{array}{l}\text { Complete } \\
\text { plagiarism }\end{array}$ & $\begin{array}{l}\text { Intellectual theft/ } \\
\text { stealing }\end{array}$ & $\begin{array}{l}\text { Takes a study/work from another author and submits it } \\
\text { under his/her name }\end{array}$ & $2.3 / 8.8$ \\
\hline
\end{tabular}

- Review all the sources from literature and write your manuscript in own words keeping all primary/secondary sources aside

- Some authors with poor command on English language should join courses on English subject

- Always take pride in giving credit to references because plagiarism occurs when someone deliberately/accidently present another person's work as their own by neglecting the original source

- Don't rush in completing the work, as haste leads to finding shortcuts and further gives birth to plagiarism

- Self-check of plagiarism by using PDT as various PDTs are available, even free of cost also, which all reduce the chances of rejection of manuscript

- Use of quotations, in case of verbatim copy paste, for example some table, is exactly copies from some source than proper citation and credit should always be kept in mind

\section{Responsibility of Editors}

"A good editor is someone who cares a little less about the author's needs than the reader's"

Dene October

- All the journals must have a policy on plagiarism which describe percentage of accepted plagiarism

- Editors must use their own judgement rather than just following reviewers view about the article

- Editors must have an access to reliable PDT and should use it regularly to do similarity checks and detecting plagiarism

- All submitted manuscripts with frank plagiarism should be returned back for correction

- Editor of the journal must issue a certificate about acceptability of the article in journal after performing reliable similarity checks and detecting plagiarism by using PDTs.
Points to Remember_Plagiarism includes but not limited to -

- Copying coursework essays

- Using published work without reference

- Collaborating with any other person when the work is shown to be individual

- Submitting another person's work as our own

- Use of unacknowledged material published on the web

- Copying another researcher's work/results

- Falsifying results

- Purchase of model assignments

\section{Conclusion}

According to Chamber's dictionary, a plagiarist is a kind of thief who steals the thoughts and writings of others and gives them out as his own. In this era of increasingly sophisticated aids, numerous softwares and PDTs are available with the editors of journals to detect the validity and genuineness of the submitted work. Teaching publication ethics to the students improves the perception of learners about this issue.

\section{References}

1. Brenan M, Nurses Keep Healthy Lead as Most Honest, Ethical Profession [Internet]. Gallup.com. 2017 [cited 23 July 2020]. Available from: https://news.gallup.com/poll/224639/nurses-keep-healthylead-honest-ethical-profession.aspx.

2. Smedley A, Crawford T, Cloete L. An intervention aimed at reducing plagiarism in undergraduate nursing students. Nurse Educ Pract 2015;15(3):168-173. DOI: 10.1016/j.nepr.2014.12.003.

3. Types of Plagiarism Infographic [Internet]. Ithenticate.com. 2020 [cited 23 July 2020]. Available from: http://www.ithenticate.com/resources/ infographics/types-of-plagiarism-research. 